\author{
Людвиг Селимски \\ Шльонски университет в Катовице (Полша) \\ Институт за славянска филология \\ ORCID: : e-mail: selimski@wp.pl
}

\title{
Диалектна основа на Pastirska knigha (1848) от Андреа Канова. 1. Фонетика
}

\begin{abstract}
Резюме: Епископ А. Канова се е старал текстът му да е достъпен, разбираем не само за католиците в България - в него се явяват и консонантите в, ф и х, които липсват в диалекта на католиците. А ограничена (в 11 думи/16 форми) е появата на характерния за диалекта на католиците нов вокал і̀ на мястото на акцентирано ѐ. За отбелязване е и появата на вокала е на мястото на а в наречието delèc 'далеко' и в прилагателното delecni ‘далечни', както и на диалектната форма se на мястото на книжовната sa 'ca' (за 3 л. мн. ч., сег. вр.) на спомагат. глагол съм. Всички тези фонетични особености са безспорно свидетелство за това, че изследваният текст е изграден в основни линии върху диалекта на католиците.
\end{abstract}

Ключови думи: консонант, вокал, звукови промени, диалект на католиците.

Abstract: The dialectal basis of "Pastirska knigha" (1848) by Andrea Canova. 1. Phonetics. Bishop A. Canova made an attempt to make his text accessible not only to the Catholics in Bulgaria; it includes also the consonants $\boldsymbol{v}, \boldsymbol{f}$ and $\boldsymbol{h}$, typically missing in the dialect of the Catholics. And yet the appearance of the new vocal $\boldsymbol{i}$ (replacing the accented è), typical of the Catholics, is limited (to 11 words/16 forms): cetìmi 'четѐме/we are reading'; lizzito 'лицѐто/the face'; nimasce 'нямаше/there was not', obricese 'обрече се/he promised', porimnuvam 'поревнувам/I like', rastiti 'растѐте/you are growing', sledini 'следѐне/following', smilat 'смѐлят/they are trampling', tij ‘това/that', viki 'веки/already', zovise 'зовѐ ce/they call it'. The appearance of the vowel $\boldsymbol{e}$ in place of a vocal $\boldsymbol{a}$ in the adverb delèc 'далѐко/ far' and in the adjective delecni 'далечни/distant' is also noteworthy. Of equal importance is the dialect form $s \mathbf{e}$, which appears in the place of the literary sa ([Cyr. ca] '(they) are'. All these phonetic features are indisputable evidence that the studied text is built mainly on the basis of the dialect spoken by the Catholics.

Keywords: consonant, vocal, sound change, dialect of Catholics.

Авторьт на Pastirska knigha (1848) Андреа Канова е роден на 15 май 1806 г. в Италия. От 1823 г. е в Ордена на капуцините, а е ръкоположен за свещеник на 20 IX 1828 г. От 1841 г. е в Пловдив(ско), от 15 VII 1843 г. е апостолически викарий на Софийско-Пловдивския диоцез, а от 14 VII 1847 - титулярен епископ на Кроя, «миросан на 26 III 1848 г.», както пише на титулната стр. на Pastirska knigha. След четвъртвековна апостолска дейност починал в Пловдив на 10 VIII 1866 г., погребан в катедралата «Св. Лудовик» (за дейността му вж. Walczak-Mikołajczakowa 2004, 162, 165). 
Книгата е на латиница, което затруднява не само читателя, но и изследователя - той не винаги правилно ще схване българската звукова форма зад транскрипцията, за да определи езиковата/диалектната принадлежност на съответната единица и нейното лексикално и/или граматично значение. Не липсват и грешки - не само езикови, на автора-чужденец, но и най-невероятни механични размествания на буквите при подготовката на книгата за печат. Още на титулната с. 1 се забелязва излишно $\boldsymbol{s}$ в думата darsgiava 'област'. А покрай системата за предаване на българската реч с латински букви по италианския правопис, не без влиянието и на хърватски образци или съответствия, се откриват и не малко непоследователности и изключения.

Моята задача тук е - като носител на говора на българите католици в с. Житница (съкрат. Жт), Пловдивско - да изтъкна на първо време онези фонетични особености, които безспорно свидетелстват за неговата католишка диалектна основа.

\section{1. Бележки за правописа}

Доколкото може да се говори за правила при записване на българския текст с латиница, те са следните (грешки се посочват при отделни примери по-нататък):

\section{Латиница Кирилица}

c

ci

ck

g

gh

$\mathrm{J}$

$\mathrm{j}$

$\mathrm{qu}$

$\mathrm{S}$

sc

sci

sm

$\mathrm{x}$ к: delèc '(нареч. далѐко)', tacam 'такъм'

ч: (пред n): vecno 'вечно', delecni 'далечни', с алтернация $ч: \kappa$ в прилагателното за м. р. ед. ч. с наст. -ен

ч: (пред $e, i)$ : ces 'час', cilek 'човек', Cierkua 'черква'

ч: (пред $a, o, u)$ : ciakah 'чаках', borciove 'борчове', ciuli 'чули'

чк: sicki 'всички', pracke 'пръчки'

дж: (пред $e, i)$ : angek 'анджак', dargi 'държи', dargiave 'държави' (с диал. [Житница] дж за книж. ж), gioab *'джоаб, отговор'

г: (пред $e, i)$ : drughi 'други', ghiaulat 'дявольт'; среща се и пред $a$, $o$ и $u$ без това да е необходимо

И: Jssukras 'Исукръс(т)'

*й: jak 'як'; juk 'юк; товар, бреме'

к: taquivi '(диал.) такиви'

кв: jednaqui 'еднакви'

3: (между гласни, рядко): karese ‘карези’, по итал. правопис

ш: (рядко) karsilak 'кършильк', dusman 'душман(ин)', taski 'тежки’

ш: vascte dusci 'ваште души', tascko 'тежко', duscià, sciube

ш: (пред $a, o, u)$ : duscià 'душа', sciube 'иубе', izvarsciovam 'извьршвам'

3м: rasmirsloto (< *rasmirstvo 'размирица'), по итал. правопис

ж: mexdu 'между', moxi 'може', podloxa 'подложа', xivot 
xi

$\mathrm{y}$

Z

$\mathrm{ZZ}$ ж: (пред $а$ и o): хіа '(диал. [Жт] жа̣) ще', xialba 'жалба', laxiovne 'льжовни'

и: (единично): уте 'име'

3: zemè 'земя', za tozi, iz 'из'

c: horzuzluzzi, мн. ч. от (тур.) урсузлук 'злина'

ц: Otaz, venez, sarze 'сьрце', valzite 'вълците', jurnezi 'юрнеци'

ц: lizzito 'лицето', razze 'ръце'

В отделни случаи се забелязват излишни допълнения към дадена буква, които по принцип служат за уточняване на нейното звуково съответствие. Така напр. още на титулната страница - в заглавието на книгата - ще си зададем въпроса, защо knigha, а не само kniga, щом буквосъчетанието gh е потребно само в позиция пред следваща предна гласна $e$ или $i$ в същата дума. В този случай това е може би заради формата ѝ за множ. ч. knighi(te).

\section{2. Вокални промени}

2.1. Най-характерна за католишкия (павликянския) говор е застъпването на акцентирано $\grave{e}\left(<* e, * e\right.$ и - по-рядко - от $*_{b}$, а в някои села в отделни примери и от $*$ ) с нова фонема $\grave{\boldsymbol{u}}$. Тя се различава от книжовното (и общонародно) $\grave{u}\left(<\right.$ псл. ${ }^{*} i$ и $\left.*^{*} y\right)$, чийто корелат в говора е с по-ниска и широка артикулация, по-близка до тази на укр. (кирил.) $u$ и пол. (лат.) $y$, отколкото до рус. $b l$, с което я представям тук. Това ново $\grave{u}$ се противопоставя фонологично на $\grave{u}$ от етимолог. $*_{i}$ и от съвпадналото с него $* y$, от което е рус. $b l$. В първата си публикация по тоя въпрос (Селимски 1974) новото ѝ отбелязвах и с лат. i, като не смятах по-ниско учленяваното $u$ за толкова близко до рус. bl. По този начин бълг. катол. тітка 'тетка' можех да соча като най-близко до сродното и еднакво с него по форма и значение укр. тітка 'тетка'. В говора фонологичната опозиция $\grave{u}$ : b̀ се проявява на три равнища: морфологично, словообразувателно и лексико-семантично.

Морфологично равнище. При глаголите от I спр. с акцент върху флексията, като бера̀, диалектната (католишка) форма за 3 л. ед. ч. сег. вр. берѝ '(той) бере' се противопоставя фонологично на императивната (за 2 л. ед. ч.) берй 'берй'. Срв. и диал. опозиция (2 л. мн. ч.) берѐты (императив) ‘берете' - берѝты (индикатив), а също така перѐть '(импер.) перете' - перйть '(индик.) перете', четѐть - четѝты и т. н. Новото ѝ $(<\grave{e})$ се явява и в окончанията за 2 л. ед. ч. берѝш ‘береш' (вж. по-долу, т. б) и за 1 л. мн. ч. берѝм(b). Срв. и опозициите, като: nутпрѐ '(аорист, 2 и 3 л. ед. ч.) подпря' - путпрй '(презенс императив, 2 л. ед.

\footnotetext{
${ }^{1}$ Срв. опозицията «плеты 'плети' - плетѝ ‘плете'», с която Ст. Стойков илюстрира забелязаната от него тенденция в банатския говор «фонемоидните варианти |и| |ы| да се превръщат в отделни фонеми» (Стойков 1967, 52). По този начин Стойков - като един от първите - се изразява по-определено и ясно за фонологичния характер на различието между новото $\grave{u}(<\grave{e})$ и вариантите на $\grave{u}$, застъпващи псл. $*_{i}$ и $*_{y}$.
} 
ч.) подпри' - nутприи '(презенс, индикатив, 3 л. ед. ч. [да/ако/като]) подпре'; срв.

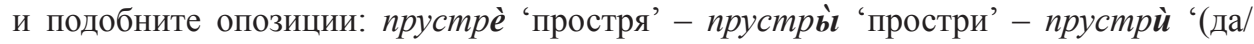
ако/като) простре'; спрѐ '(ти, той) спря' - спрй 'спри' - спрѝ '(да/ако/като) спре';

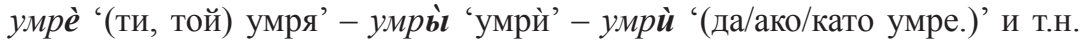

Словообразувателно равнище. Гласната -ѝ- $(<-$-̀- $)$ в катол. облик на суфикса -ѐж (> -ѝм, -йж-) на отглаголното съществително се противопоставя фонологично на тематичната гласна -ы̀- (< -й-) на глаголните форми за 2 л. ед. ч. сег. вр. от II спр. с акцент върху флексията -йm (> -ы̀ в в говора), срв.: гармѝ $u$ 'гърмѐж' (отглаг. съществ. на -ѐж) - гармы̀ш 'гърмйш’ (2 л. ед. ч.); ламмтѝ $и$ 'ламтеж’ ламмтым 'ламтиш’; пламтѝм 'пламтеж’ - пламты̀ 'пламтиш' и др. под.

Лексико-семантично равнище. Числителното редно ж. p. nѝma 'пѐта' се различава от съществителното име nы̀ma 'пита' и от глагола nы̀ma 'пита

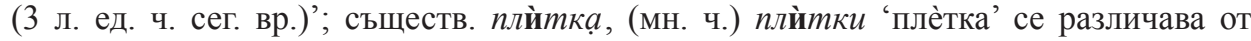
прилагателното име (ж. р. ед. ч.) пль̀тка, (мн. ч.) пль̀mки '(ж. р.) плитка, -и'.

В изследвания текст ярката диалектна промяна на ’̀ в нова фонема $\grave{u}$, различна от книжовното (и общонародно) $\grave{u}$, се открива в малък брой случаи - тя е била съзнателно избягвана. Понеже в някои публикации върху подобни източници се изтъква, че коментираната тук особеност уж не е намерила отражение, а - фактически - не е била забелязвана от някои автори, тук ги посочвам изчерпателно (11 думи в общо 16 употреби):

cetìmi 'четѐм': Akó cetìmi na stari kitape od okomuscete se kazova ci imaha mlogo veri ama siga nemaghi veki $(20)^{2}$; se ceti 'четѐ се (в смисъл: брои се, смята се)': sadaka deto se poiska od vas se ceti dip manenka (26);

lizzito 'лицѐто': sas tolkova rados i veselia na lizzito, sas tolkova mir u dusciata (21). За да не си мислим, че може би се отнася за редукция на $e(>u)$, ще добавя, че в говора льций 'лицѐ' се различава от льџџы 'външната (предна/ по-хубава) страна (на нещо)';

nimasce 'нямаше', в говора предполагащо изходно нѐмам от стб. нє инынь (БЕР IV: 732-733), а не от нъмамъ: Sveti Jovan [...] u sickite negovi knighe, kaktó da nimasce drugho, zaman naracesce bratska millos (7); nimakaghi 'нямаха (в смисъл: нямаше) ги; липсваха': Na tuà ureme gherciek se vidat po svetat mlogo veri, kojeto nimakaghi na staro ureme (20); nimaghi 'няма ги': zashto nimaghi na staro ureme (20);

obricese 'обрече се, обеща' (17, 2 пъти), в говора убрйчы се̂; pak se obrice 'пак се обрече' (17); срв. простата форма рѝче 'рѐче’ (Милетич 1910, 8);

porimnuvam 'харесвам, пожелавам': Tuà nescto porimnuvam, i iskam (28); срв. порѐвнувам (се) 'харесвам (се)', порѐвна (диал.) 'пожелая, поискам, харесвам’ (Геров 1978, 207; БЕР V, 528-529);

rastiti 'растѐте (2 л. мн. ч., индикатив)': od den na den da rastiti na dovarscina od kristianskite kreposti (25); в говора индикат. форма растѝты се различава от императ. (2 л. мн. ч.) pacmèmы (в книжовния език pacmème е за индикатив и за императив);

\footnotetext{
${ }^{2}$ Цифрата в обли скоби е страницата, на която се намира съответният пример или фрагмент.
} 
sledini 'следѐне': da j poklonevati vascto sarze, ama povici sas sledini od nejnite kreposti da ja proslaviti (26). Едва ли е с редукция от *слѐдене, от хърв. slijèdēnje;

smilat 'смѐлят, стъпчат': i sickata onaja kraunisctina deto moxiat da smilat horata kolandrisovaha da maciat kristianete (21);

tij 'това': tij pak je moja zdrava volia da smisla (28); в други източници: tij mojè nevòlno tèlo; Tij odpusctènie (Arabagiski, Jakovsky 1844, 140, 155), tij knigice (Jakovsky 1866, 149, 150). Местоим. tij е с вокал $u$ под влияние на близките по форма и значение местоимения ний 'него' за 3 л., ед. ч., ср. р., гломерат. падеж (Селимски 2006: 44-45) и сий 'тьй, така' от псл. *sbjb (Селимски 2015, 311-312; срв. Селимски 2017, 292);

viki 'вече' (9) - срещу 4 появи в облик veki; от диал. вѐке, вѐки 'вече', тук и с катол. ново ѝ $(<* e)$, срв. стб. вщк, пол. шіе̨сеј 'повече' (БЕР І, 139);

zovise 'зовѐ се, нарича ce': kojà zovise dirèk (16); emi se zovì joscti nascia Majkia millostiva (25).

На фона на представената промяна, доста осезателна и - затова - съзнателно избягвана, честата поява на относителното местоимение kojeto вместо формата за мн. ч. kojito се представя като резултат от свръхстарателност - доколкото не се отнася за хрв. које за ж. р. мн. ч. вин. (= им.) пад., побългарено с членната морфема -to.

2.2. В говора псл. *ja в позиция след съгласна се застъпва от гласна $e$. За отбелязване в текста на еп. Канова е zете (< псл. *zemja) 'земя': zlocesta zemè; tazi zemè $(9)$, na zemeta 'на земята' $(12,27,28)$, na maja zemè 'на тая земя' $(13$, maja с погр. $m$ вм. $t$ ); mestà od zemeta 'места на земята' (18). За този облик, съответстващ на земеे 'земя' в Житница, Ореш, Свищовско (Стефанова 1991, 116) и в банатския говор (Стойков 1968, 88-89), в БЕР I не се споменава. Псл. *е̌ обикновено се застъпва с $e$, за други субституции вж. Прегласи (2.8).

2.3. В говора псл. *e покрай $e$, както в прилагателното мек 'мек', в позиция под акцент се застьпва в някои примери с новото $\grave{u}$, както при $\grave{u}(<$ псл. *e, срв. 2.1). Но в отделни случаи псл. *е се застьпва в акцентна позиция от гласната $\boldsymbol{b}$,

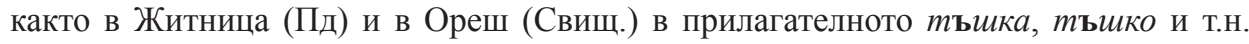
и с обобщено $ш$ (от формите с -ик-<-жк-) и за мъжки род тышък срещу книжовното (и общонародно) тѐжък (от псл. *tęžьkъ). Прочеe, няма съмнение, че в нашия текст нареч. tascko 'тежко' (27) застьпва не книжовното тѐжко, а диал. католишко тъшку; срв. и taski borciove 'тежки (преносно) задължения' (5).

2.4. Забележителна особеност е появата на гласна $e$ в основата на наречието delèc 'далеко; далече': delèc od nej (3), delèc od vas (13) и прилагателното от него delecni ‘далечни': delecni mestà; Viliate [...] delecni (18), delecni veliate (27). По изглас подобно на диал. далѐк (БЕР І, 315), то е точно съответствие на диал. делйк(y) и делѝчин в Житница, и - по Дипл. раб. - в Ореш (Свищ.), ако се абстрахираме само от прехода на $\grave{e}$ в ново $\grave{u}$, който еп. Канова съзнателно е избегнал. Прилагателното делѐк 'далечен' (и делѐку 'далеко'), отбелязано в с. Дервент, Дедеагачко (Бояджиев 1970, 227), се привежда в ЭССЯ $(4,184$, s.v. *dalekъ[jь]), но без коментар за гласната $e$ в основата. И така, не може да има сьмнение, че чрез вокала $e$ в първата сричка на delèc и delecni текстьт на еп. Канова се свързва 
с католишкия ареал. А промяната $a>e$ трябва да е резултат от регресивна асимилация $(a-\grave{e}>e-\grave{e})-$ уподобяване на неакцентирания вокал $\boldsymbol{a}$ по акцентирания $\boldsymbol{e}$.

2.5. Рядка особеност, характерна за катол. говор, е формата на спомагат. глагол $c ъ м$ за 3 л. мн. ч. сег. вр. се̂ '(те) са' и - под акцент - нbl cề '(те) не са', застъпваща стб. сть (< псл. *sętь). Гласната в отрицат. форма ны сі̀े '(те) не са’ е съща-

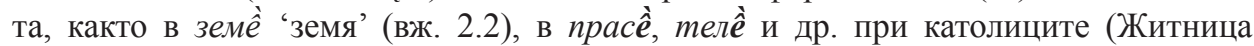
и Ореш) и в банатския говор (Стойков 1968, 88-89, 180, 231). Тя е добре представена у еп. Канова: i pogolemi se bili razgovokite, deto sti mi dali (5; с пропуснато $r$ от *razgovorka '[прен.] утеха'); sickite [...] promisleni se uceleni (6); teja mojè misleni, i hurtì ni se tukuci [...] od mojet jezik (6); oh kolko scteha sicki da se ciastili na tazi zlocesta zemè (9; с погр. ciastili вм. *ciastiti 'честити'); kristianete [...] se na jedno zdruxeni (10); hora, kojè na yme Boxi se na jednó izbrani (11); tej se dukare [...], ako negovite dela se mexdu teh [...] izbrane 'събрани' (12); polovernizite [...] $\boldsymbol{s} \boldsymbol{e}$ na jednó zdruxeni, a kaktó ni se zdruxeni na Jme Boxi [etc.] (14); ipak sickite drughe veri se laxiovne, zasctò $n i$ se zadadine od Bogha (15); ima po jedni mexdu vam, deto se sebép od kaughì (16); drughe veri se krivi, i laxiovne (18); kaktó se sciahate ('свидетели') knighite od oneja Redovnizi; taquiva ni se sickite drughe veri (19); pak tezi veri $n i$ se rasilane po sickia svet; etto indici taquiva veri se laxiovne (20); spored nej pak se razdali bisbroi knighi, i kitape (21); ci dip malko se oneja deto se ispazavat zascto dip malko se, deto iz varsciovat zakonete od Issukrasta; zerè duma Issukras, ci mlogo se vikani, a malko se odbrani (24); zere na filbe ima katolizi, i ci se sarzoviti da rastilet slavata od Bogha (26).

2.6. Редукция на неакцентираните широки гласни $(e>u ; o>y)$, известна и в други говори (редукцията на $a[>$ b ] не е отразена - в транслитерацията, приложена от еп. Канова, бълг. в се предава с лат./бълг. $a$ ):

2.6.1. Редукция на $\boldsymbol{e}>\boldsymbol{u}$ : пi тох $i$ 'не може', povici 'повечe', zemi 'взѐмe' (3), sigà 'сега', сi 'че' и др. Както и в говора, явява се в наст. -ni (< -не/-ние): pocivani, kazandisovani, praveni, redeni (3), iskani, ubaxdeni, odredeni (4) и др.; в наст. -in < -ен (за прилагателни / причастия): falin; dovarscino (3), nakicin (4), dlaxin (5), verin (8), zemin raj (9), silin 'силен' (12), dostoin 'достоен' (14) и др., но срв. propadena 'пропъдена' (9).

Глаг. оконч. за 1 и 2 л. мн. ч. -м(е) и -те се явяват с гласна -u (-mi, -ti): ci se maciti da xiveiti (5), varviti; znajti 'знаете'; xia baditi 'ще бъдете' (6), zaminevami 'заменяваме' (8) и др. Обаче отглаголното съществ. (мн. ч.) izmamite 'измамите' е с гласна $\boldsymbol{e}$ в членната морфема -te/-me: izmamite od paklenski dusman 'душман' (6). А така е и в говора (Житница): съществителното (мн. ч.) изма̀м-bl-me е с гласна -e в члена - за разлика от положението ѝ в еднаквата по фонемен състав (и акцентуация) глаголна форма изма̀м-blmbl, с оконч. -blmbl, с изгласно -bl $(<-u<$ редуц. -e) - срещу книж. $-u-m e$.

В някои случаи с окончание -e за мн. ч. на имена от женски - $a$-основи вместо - и може да се отнася не за фонетична промяна, а за морфологична особеност - прилагане на окончание «по хърватски образец», срв. напр. knighe (7), покрай knighi (21) и knighite (19), pracke 'пръчки' (12) покрай prackite (13). 
Спомагателният глагол съм е с редуцирана гласна -е (> -u): $\operatorname{smi}$ 'сме' (14,

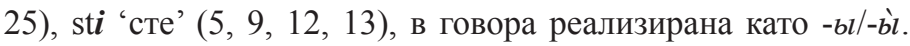

2.6.2. Редукция на $\boldsymbol{o}>\boldsymbol{y}$ : $\operatorname{pom} \boldsymbol{u} \mathrm{sc}$, $\operatorname{pom} \boldsymbol{u}$ sce 'помощ(и)' $(5,11,19,22,28)$; $\boldsymbol{u b a r}$ na na Verata povici pugane (10); kojato mi $\boldsymbol{u}$ badi ci sam odbratn '(с излишно t) избран', срв. хрв. ödabrān (4); takova ubaxdeni (4); da mi ubadi negovata prisveta volia (4); i da $\boldsymbol{u}$ baxdet na kristianete (7); drugh pat im $\boldsymbol{u}$ baxdisce (8); tazi millos $\boldsymbol{u b a r n a}$ na Verata povici pugane (10); praudini od Bogha ubadine 'обадени' (15); od Bogha ubadino (15); verata ubadina od Bogha (16); i se $\boldsymbol{u b a d i h a}$ na svetat (20); zgudenika 'сгоденика' (23); scta da vo $\boldsymbol{u}$ bada (25).

2.6.3. На фона на редукцията са очевидни и случаи с хиперкоректно правоп. $o$ вм. $y$ (лат. u): ossilni ' $y$ силни' (7), ostà ' $y$ ста' (10); л. мест. за 1 л. мн. ч. то (вин./дат. пад.) срещу диал. (Жт) му 'нас, ни; нам': zaman mo prekazovasc 'винаги ни приказваш' (8); л. мест. за 2 л. мн. ч. vо (вин./дат. п.) срещу диал. (Жт) ўу 'вас, ви; вам': trebe da vo je dragho kato znaiti; Napokom oh kolko trebe da vo je strascno, kató znajti (11); в турцизми: кovèt от ap.-тур. kuvvet 'кувет; сила' (3), horzuzluzzi, мн. ч. от урсузлук 'злина' (< тур. uğursuzluk) 'липса на късмет' (9); oighun от тур. uygun 'сходен' (10) и др.

2.6.4. Явление обратно на редукцията е появата на вокала $\boldsymbol{e}$ на мястото на неударено $\boldsymbol{u}$. Макар и да изглежда като свръхстарателен изговор или/и правопис, в някои случаи това се дължи на по-ниската му и широка артикулация, характерна за говора, т.е. като вокала $\boldsymbol{e}$, както напр. в: naistena (7), istenska 'истинска' (9).

В много случаи префикс при- се явява като пре-: da se prebira 'да се прибера', prejah 'приех' (4), prekazova 'приказва' $(8,19)$, prelika (в говора акцентът е на втората сричка) 'прилика' $(9,15,20)$, prebrahase 'прибраха се', prebrana 'приета' na sekoj mesto (19), prejmet ‘приемат' (22), Precisteni ‘причастие' (24), Рreiemeti ‘приемете’ (28) и др.

2.7. Синкопа и полувокализация на неударени гласни предимно в средисловие и в изглас: vascta 'вашата' (14), vascto (14); sirmasi 'сиромаси' (25); onvà 'онова' (7); sekoj mesto 'всякое' (19), da se znaj 'знае' (26); filbe (26), от filibe, тур. облик на Филипопол (Пловдив), срв. Filibeliskata darsgiava (1, още и с изпадане на $\boldsymbol{j}$ : суф. -isk- <*-ijsk-), както в говора; Mastor 'майстор; учител', с изпадане на $\boldsymbol{j}$ (7) и др. Тези промени се срещат в много говори и в разговорната реч.

2.8. Прегласи на гласни. В позиция след съгласните $\check{u}, u, u$, ж предните гласни могат да се променят в задни и - обратно - задните в предни:

2.8.1. Преглас $\boldsymbol{a}>\boldsymbol{e}$ : ces 'час': na smastin ces, с погр. smastin вм. smartin (12), срв. диал. (Жт, в молитва) на смъртин чес; чесът, чѐска, заўчѐс 'завчас'; cek 'чак' (17), както и в Жт; zaraceno 'заръчано', zaracem, naracem, da se obìcet (7), kojto obice; da se ubiceti; usesctemse 'усещам ce' (3); ubaxdeni 'обаждане' (4) и др. Този преглас се явява, както и в говора, и след други палатални консонанти: tej se razgovarem 'разговарям (в смисъл) утешавам ce' (5), izlazet 'излазят' (6), da ubaxdet 'обаждат' (7), da ja razvalet 'разва́лят’ (21) и др. В говора този преглас се явява в много глаголи от III спреж. в презенс и имперфект, срв.: pak naracesce sveti Paole; zaman naracesce (7). Тук спадат и глаголи, чиято основа завършва на твърда съгласна, 
както напр. в диалектните (Жт, Ореш) разбырем, упьрем (Стефанова 1991, 45), каквито се явяват и в текста на еп. Канова: da se opirem (4, 2 пъти; 5).

2.8.2. Преглас $\boldsymbol{e}>\boldsymbol{o}$ : gioab, с преглас $(e>o)$ от тур. cevap, -b1 'отговор': Vecniat Suditel, ta na nego gioab da davam (3), срв. диал. (Жт) джуа̀n 'отговор (на Страшния съд)', с редукция на *o (> $y)$ и изпадане на 8.

2.8.3. Личните местоимения за 1 и 2 л. мн. ч. nia 'ние' и via 'вие', отбелязани в контекстите: Nia sé imami strah od Bogha; Nia sirmasi sinove (25); via jako dobré znajti; Via xia baditi mojat venèz mojata rados (6); via mojè draghi sinove (9); dordè via sti izbrani sicki na jednó, via scte da baditi jaki (12) и т.н., са характерни за говора в Житница.

\section{3. Консонантни промени}

3.1. В говора (на Жт) липсват фонемите $8, \phi$ и $x$. Обикновено те изпадат или съвпадат в полувокал $\check{y}$, а фонем. $\boldsymbol{x}$, освен това, в позиция между вокал и консонант се променя в полугласна $\check{\boldsymbol{u}}$. Но тези промени се срещат и в други говори, затова и не са от голямо значение. В текста на еп. Канова те се констатират в малко примери, а фонемата $\phi$ се явява нормално, за разлика от изпадането/застьпването ѝ с полугласна $\check{y}$ (в Жт).

3.1.1. Изпадане на v: sicki, sickite 'всички' (6, 7, 9 и др.), sickiat 'целият',

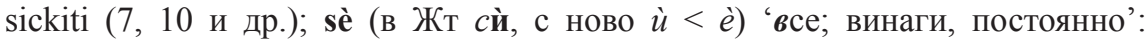
jednà odejà cesto izmetina, cista sè biva (24), Nia sé imami strah od Bogha (25), i via sè da se dargiti cisti (26); gioab, с изпадане на $\mathbf{v}$ от ap.-тур. cevab 'отговор' (и преглас $e>o$, срв. 2.8.2); kakò 'какво' $(4,5,12,14,15,18)$; tuà ‘това' $(3,6)$ : zarád tuà 'зарад това'; Za tuá (5), kakoto ‘каквото’ (6, 11 и др.); tuarat 'товарът' (3); mirsto *'мирство' (3, 9), rasmirsloto (вм. *rasmirstoto, с наст. -stvo (10); zarsto 'царство' (13, 23), zarstà, мн. ч. (20); ina po jednì zarstà (20), tej da ghi uvedat na poloverstoto (22), na tuà Zarsto (23), moghuscto (23), с изпадане на $\mathbf{v}$ от суф. -stvo (> -sto) и опростяване на конс. група ćs (> ̌̌ ) от хрв. mogüćstvo, покрай което се явяват още 4 сродни срещу частично побългареното Moghakia (25).

3.1.2. Вокализация на $\mathbf{v}(>\mathrm{u})$ пред съгласни: ureme, вм. *vreme $(3,20,21,28)$ и при предлога $v$ 'в': U $\operatorname{Rim}(1), u$ cilesko sarze (3), u kascti (26).

3.1.3. Полувокализация на $\mathbf{v}(>$ u, записвана като u): ouze 'овце' $(5,6)$, срв. ŏy $u$ е̂ (в Жт) след числително, а иначе $y u \hat{e ̀ ~-~ с ~ р е д у к ц и я ~ н а ~} o$ - (> $y$-) и изпадане на $-\check{y}$ - $(<6)$; pastir da napusne ouzetezi 'овцете си' (6), praudinà, вм. *pravdina (18), pra $u$ diuá 'правдива' (19), pra $u$ dinì (20); pra $u$ dinà; praudinite (22).

3.1.4. Асимилация: vn $>\mathrm{mn}$, известна в говора, напр. в грымна < гривна. Явява се в: ramin 'равен' (24), както в Жт ра̀мин, обобщена от формите ра̀мнa, ра̀мну и т.н.; Tuà nescto porimnuvam 'харесвам', срв. (у П. Р. Славейков) поревнал 'харесал' (28).

3.2. Изпадане на h: Ah kolko prazno arceni praviti vez den u kascti! Kolko pari arciti 'харчене, харчите' (26). 


\section{3. Палатализация и депалатализация}

3.3.1. Наст. -ка за съществителни от ж. род се реализира в говора с палат. $\kappa$ ' (-к’a): Blaghodaritelkia, majkiata (24), Majkia millostiva, Majkia Deviza Maria (25) и др.

3.3.2. Депалатализация на палаталните съгласни, наблюдавана в глаголната флексия, в примери като: kakò da prava 'правя' (4), da vida ‘видя' (5), paza ‘пазя'(6), da pravat 'правят' (15), sledat 'следят' (17) и мн. др.

3.4. Други консонантни и вокално-консонантни промени, характерни за говора

3.4.1. Наречието na dlagho 'на дълго' (8) и прилагателното в dlagh xivot (27) са според облика им в говора (Жт) длъгу, длъга и т. н., както и родопските длек, дл'оิк и длик (Стойчев 1965, 152), от стб. Альг' (БЕР І, 456), при което длик 'дъльг' (Стойчев, ib.; Тончева, Илиев 2016, 119) е с вокал $u(<\grave{e}<b)$, както при католишкия/павликянския преход на $\grave{e}(>\grave{u}$, срв. 2.1).

3.4.2. Преглас на палатално $\boldsymbol{\partial}$ '> 2': ghiaulat 'дяволът' $(8,11)$ и в производните ghiauleteni ‘дяволии' (17) и ghiausctini ‘дяволщини’ (21).

3.4.3. Преход на консонанта $\boldsymbol{c}$ в интервокална позиция в $\boldsymbol{u}(c>u)$ в глагола късам, който в Жт, както и в Ореш (Свищ.), звучи къцам: trikatno vaxie lesno se ni izkazova 'скъсва' (12); срв. съответствието му и в говора на с. Момчиловци (Смолянско) коิฺ̣̀м 'късам', скоิ̀ввам 'скъсвам' и др. произв. (Каневска-Николова 2001, 66), между другото, и с родопското «широко о».

$$
* * *
$$

В заключение може да се каже, че от гледна точка на фонетичните му особености, езикът в Pastirska knigha на еп. Андреа Канова до голяма степен се базира върху говора на католиците в Пловдивско и Пловдив. «Пастирът» се е колебал между общобългарската (или книжовната/«градската») фонетика, от една страна, и изговора при неговите «ouze» (срв. 3.1.3) - католиците, от друга. Макар че в говора (в Жт) няма съгласни в и $x$, в текста му те се явяват, с малко изключения. Епископът е предпочитал съответните словоформи с $в$ или $x$ като книжовни (и градски в Пловдив), без да са при това неразбираеми за католиците. Но системно се е придържал към католишкия говор от гледна точка на ятовата гласна - напр. в текста срещаме само mesto и vera, а не - *miasto или *viara, въпреки че католишките села в Пловдивско съседстват от повечето, ако не и от всички страни с носители на ятов говор, да не говорим за самия Пловдив. А бяха изтъкнати и някои ярки фонетични черти на говора, чието отражение в текста не може да се счита за резултат от съзнателния избор на епископа - за повечето от тях той, италианецът, едва ли си е давал сметка. Това може би се отнася и за най-ярката черта на вокалната система на говора, каквато е преходът $\grave{e}>\grave{u}$. Малкият брой примери с новата фонема $\grave{u}$ са по всяка вероятност случайни пропуски - много повече са примерите в изучавания текст с вокал ѐ, чиито съответствия в говора са с новата гласна $\grave{u}$. Това без съмнение се отнася и за появата на вокала $e$ на мястото на $a$ в наречието delèc 'далеко' и в прилагателното delecni 
'далечни', както и на диалектната форма se на мястото на книжовната sa 'ca' (за 3 л. мн. ч., сег. вр.) на спомагателния глагол съм.

Всички разгледани тук фонетични особености са безспорно свидетелство за това, че езикът на Pastirska knigha (1848) от еп. Андреа Канова в основни линии е свързан с диалекта на католиците.

\section{Литература}

БЕР I, IV, V, Български етимологичен речник [Bŭlgarski etimologichen rechnik], т. I, IV, V, София 1971, 1995, 1996.

Бояджиев Т. [Bojadzhiev Т.] (1970), Из лексиката на с. Дервент, Дедеагачко [Iz leksikata na c. Dervent, Dedeagachko], [в:] Българска диалектология. Проучвания и материали [Bŭlgarska dialektologîia. Prouchvanîia i materiali], т. V, София, с. 223-243.

Геров Н. [Gerov N.] (1978), Речник на българския език [Rechnik na bŭlgarskiia ezik], ч. 4: $\Pi[P]$, фототипно изд. [fototipno izd.], София.

Каневска-Николова Е. [Kanevska-Nikolova E.] (2001), Говорът на село Момчиловци, Смолянско - половин век по-късно [Govorüt na selo Momchilovtsi, Cmoliansko - polovin vek po-kŭsno], София.

Милетич Л. [Miletich L.] (1910), Павликянското наречие [Pavlikianskoto narechie], [в:] Сборник за народни умотворения, наука и книжнина [Sbornik za narodni umotvoreniia, nauka i knizhnina], т. XXVI, (Отделен отпечатък [Otdelen otpechatŭk]), София.

Селимски Л. [Selimski L.] (1974), Българската диалектна фонемна промяна ѐ > ̀̀ [Bŭlgarskata dialektna fonemna promiana è > ù], [в:] В памет на Проф. Стойко Стойков (1912-1969). Езиковедски изследвания [V pamet na Prof. Stoǔko Stoǔkov (1912-1969). Ezikovedski izsledvanîia], София, с. 183-187.

Селимски Л. [Selimski L.] (2006), Етимологични поправки, уточнения и допълнения [Etimologichni popravki, utochneniīa i dopŭlneniia], [в:] Националният език в условията на чужди влияния и глобализация. Научна конференция, посветена на 125-годишнината от рождението на акад. Стефан Младенов (София, 28-29 юни 2005) [Natsionalniiat ezik $v$ usloviiata na chuzhdi vliianiîa $i$ globalizatsiia. Nauchna konferentsiia posvetena na 125-godishninata ot rozhdenieto na akad. Stefan Mladenov (Sofiia, 28-29 îni 2005)], Coфия, с. 40-46 [= Селимски 2016, 102-111].

Селимски Л. [Selimski L.] (2015), Об этимологии двадиати слов. Дополнения и исправления $\kappa$ Болгарскому этимологическому словарю [Ob etimologii dvadtsati slov. Dopolneniia i ispravleniia $k$ Bolgarskomu etimologicheskomy slovariu], [в:] Памяти акад. Олега Николаевича Трубачева к восьмидесятилетию со дня рождения (23.10.1930-9.03.2002) [Pamiati akad. Olega Nikolaevicha Trubacheva $k$ vos'midesiatiletîu so dnîa rozhdeniia (23.10.1930-9.03.2002)], Труды Инст. русск. языка им. В.В.Виноградова [Trudy Inst. russk. iazyka im. V.V. Vinogradova], т. IV, Этимология [Etimologîia], Москва, с. 303-322.

Селимски Л. [Selimski L.] (2016), Етюди по етимология и ономастика [Etiudi po etimologîa i onomastika]. Studia z etymologii i onomastyki, Велико Търново.

Селимски Л. [Selimski L.] (2017), За произхода на петнайсет български думи [Za proizkhoda na petnă̌set bŭlgarski dumi], [в:] Ob jubileju Ljubov Viktorovne Kurkine, ur. M. Furlan., S. Torkar, P. Weiss, Jezikoslovni zapiski 23/2, Ljubljana, c. 287-296. 
Стефанова А. [Stefanowa A.] (1991), Говорът на с. Орещ. Общи особености с акиент върху словообразуване [Govorŭt na s. Oresh. Obshchi osobenosti s aktsent vürkhu slovoobrazuvane], дипломна работа [diplomna rabota], Велико Търново.

Стойков Ст. [Stořkov St.] (1967), Банатският говор [Banatskîiat govor], София.

Стойков Ст. [Stō̌kov St.] (1968), Лексиката на банатския говор [Leksikata na banatskiia govor], София.

Стойчев T. [Stořkov St.] (1965), Родопски речник [Rodopski rechnik], [в:] Българска диалектология. Проучвания и материали [Bŭlgarska dialektologiiá. Prouchvaniïa $i$ materiali], кн. II, София, с. 119-314.

Тончева Хр. [Toncheva Hr.], Илиев Ив. [Iliev Iv.] (2016), Говорът на село Припек, Джебелско [Govorŭt na selo Pripek, Dzhebelsko], Пловдив.

ЭССЯ 4 [ËSSIĀ 4], Этимологический словарь славянских языков. Праславянский лексический фонд [E்timologicheskii slovar slavianskikh iazykov. Praslovianskii leksicheskii fond], вып. 4 (*čaběniti - *děl’a), ред. О.Н. Трубачев [O.N.Trubachev], Москва 1977.

Arabagiski P., Jakovsky J. (1844), Nauka kristianska za kristianete od Filibeliskata darxiava, Rim.

Jakovsky J. (1866), Nad-hortuvane [в:] Knigice od molitvi [...] K. Pooten, biskup od Maronia i apostolski namestnik od Antivari, Rim, c. 149-150.

Pooten K. (1866), Knigice od molitvi [...] K. Pooten, biskup od Maronia i apostolski namestnik od Antivari, Rim.

Walczak-Mikołajczakowa M. (2004), Piśmiennictwo katolickie w Butgarii. Język utworów II potowy XVIII wieku, Poznań. 